\title{
Financial Behavior of Family Businesses: A Bibliometric and Systematic Literature Review
}

\author{
Oumaima Quiddi ${ }^{1} \&$ Badr Habba $^{1,2}$ \\ ${ }^{1}$ Research Laboratory of Organizations Management (LAREGO), Cadi Ayyad University, Marrakesh, Morocco \\ 2 Moroccan Family Businesses, ESCA Business School, Casablanca, Morocco \\ Correspondence: Oumaima Quiddi, Research Laboratory of Organizations Management (LAREGO), Cadi Ayyad \\ University, Av. Allal El Fassi BP 3748 Amerchich, Marrakech, Morocco. Tel: 212-52-430-4692.
}

Received: September 16, 2020

Accepted: November 12, 2020

Online Published: January 11, 2021

doi:10.5430/ijfr.v12n2p75

URL: https://doi.org/10.5430/ijfr.v12n2p75

\begin{abstract}
The aim of this paper is to identify some holistic insights and to assess the evolution of the "financial behavior of family businesses" as a field of research. Authors performed an objective, and comprehensive analysis using a bibliometric and systematic review. Thus, three major databases (Scopus, Web of Science, and EBSCO host) were queried and 256 retrieved publications were analyzed. Findings showed an increasing dynamic of the number of publications from 1990 to 2020 . The text mining of retrieved publications enables a thematic analysis of the intellectual streams and key concepts underpinning financial policies within family businesses. From a managerial perspective, a review of literature on financial behavior can help raise awareness among family members, managers, and policymakers about family business' peculiarities that make the financial decisions complex. Finally, this paper reveals trends but also some knowledge gaps to consider in future research about the study of financial decisions within the context of family businesses.
\end{abstract}

Keywords: family firm, financial policy, investment, capital structure, dividend

\section{Introduction}

Over the last decade, literature has paid increased attention to the psychological and sociological dimensions within the framework of a new field called behavioral finance. Thus far, financial decisions became increasingly complicated in the presence of psycho-social factors and relationship issues. The case of family businesses is relevant to illustrate that statement. There is no question that family businesses are recognized as the oldest and most predominant form of business worldwide. It reflects two-thirds of the world's economic structure (Michelli, 2014). Besides, more than $60 \%$ of companies in Europe and the United States of America are owned by families (Ernst \& Young, 2013). In the Middle East also, this category of business represents 90\% of firms (Moussa \& Elgiziry, 2019). Not surprisingly, the prevalence of family firms makes them a leading type of business (Sharma Chrisman \& Gersick, 2012) and a cornerstone of overall socio-economic development (Poutziouris, 2006). In concrete terms, family businesses participate considerably in investment promotion and job creation, which make them a key pillar of the economy, social development, growth, and competitiveness.

For its part, the literature on financial behavior is large but, paradoxically not conclusive. There are mainly three financial decisions that can influence the firm value which are investment decisions, financing decisions, and dividend decisions (Chaleeda, Islam, Ahmad \& Ghazalat, 2019). Besides, financial decision-making is a priority concern for any form of business. It is one of the management challenges that affect the growth and survival of the firm (Van Auken, Ascigil, \& Carraher, 2017). The process becomes more challenging in the presence of behavioral variables (Auken, 2005).

The main purpose of our research is to help identify trends and directions in the literature related to the financial behavior of family businesses through a systematic review of previous research. We limit ourselves to the description and synthesis of the existing literature and the identification of new research avenues about this topic. In this regard, the remainder of this paper is structured as follows: section two contains conceptual boundaries and background. Section three presents methods that have been applied to select data and to carry out the bibliometric and the systematic analysis. Section four reports results and the final section include discussion, directions for future research, 
and conclusion.

\section{Literature Review}

Previous studies on the financial policies and the financial behavior of family businesses provide the context for this review. The following sections clarify the conceptual boundaries and develop a framework for three major terms: family business (1.1), financial behavior (1.2), and financial policies (1.3).

\subsection{The Family Business: A Controversial Definition}

There is no universal or commonly accepted definition of the family business. However, we can assert that it is a business controlled and governed by a dominant coalition of family members with the purpose to maintain sustainability across generations and to defend a long term vision (Arregle, Hitt, Sirmon \& Very, 2007). Scholars generally agree that it is the family's involvement in the business that makes it a family business with the intention of family members to retain ownership (Schulze, Lubatkin, Dino \& Buchholtz 2001). Therefore, the attribute of "Familiness" is a key criterion in defining a family business (Chua, Chrisman \& Sharma., 1999). Besides, preserving family control and transgenerational succession is of paramount importance to develop a family business (Gottardo \& Moisello, 2019; Berrada El Azizi \& Habba, 2018).

Broadly, family businesses are different from non-family ones (Moussa \& Elgiziry, 2019) since family ties reflect a socio-economic background, culture, and value system, which impact the decision-making process (Seaman, Bent $\&$ Silva, 2019). By reference to the nature of purposes, it can be argued that family businesses tend to be challenging because, in addition to managing common business needs and opportunities, they must take into account the needs and desires of the owning family. Beyond financial performance, family businesses aim for continuity and growth (Brenes Madrigal \& Requena, 2011) in addition to socio-emotional wealth (Gomez-Mejia, Haynes, Núñez-Nickel, Jacobson, \& Moyano-Fuentes, 2007). Consequently, the dual dimension (family \& business) legitimizes and gives family business decisive special features.

\subsection{Financial Behavior}

Traditional finance has treated financial policies without regard to the ownership structure of the firm. Indeed, there is no specific theoretical framework for the financial decisions within family businesses. Consequently, a specific framework is more legitimate and necessary than ever, since the particularity of family businesses has been demonstrated in several previous studies.

Interesting is the fact of studying financial behavior because, when dealing with family businesses, one cannot deny the weight and strong presence of behavioral, cultural, and attitudinal variables even when it comes to exploring or sketching out rational decisions like financial decisions. In this perspective, Chua et al. (1999) introduced the definition of family businesses by behavior. The authors argued that what differentiates a family firm is not the presence and involvement of the family, but more importantly, how this involvement establishes a vision that guides the business. More concretely, the family's vision sets the context and guides the firm's policies and functional decisions.

In the same vein, Costa, Carvalho, and Moreira (2019) pointed out that human behavior has been the subject of much discussion because it influences the decision-making process. In this respect, psychological and behavioral variables need to be incorporated into this process even when it comes to financial decisions in financial markets (Shefrin, 2010). In the particular case of family businesses, the incorporation of behavioral variables is much more legitimate. This may be justified by the presence of family ties reflecting a socio-economic background, culture, and value system that may influence the decision-making process (Seaman et al., 2019).

\subsection{Financial Policies}

Financial policies within family businesses can be delineated into three financial decisions. These are the investment, the capital structure choices, and the dividend distribution policy. Firstly, the investment decision is subcategorized into long-term investment decisions related to fixed and intangible assets and short-term investment decisions related to current assets. Secondly, the capital structure concerns the combination of funding sources. It is one of the key decisions affecting the value of the business (Nurlela, Sulastri \& Hanafi, 2019). Understanding financing decisions is of great importance for family businesses because of their "peculiar financial logic" (Michiels \& Molly, 2017). Finally, dividends are a mean of redistributing a company's profits to its shareholders and are one of the main sources of return on investment (Hultén, 2020). It is also a strategic policy that boards of directors face (Gyapong, Ahmed, Ntim, \& Nadeem, 2019). Besides, many questions about dividends in family firms remain unanswered (Michiels, Uhlaner \& Dekker, 2017). 
It is crucial to consider the joint impact of the three decisions. We assert that the financial behavior of family businesses cannot be explored by limiting oneself to one decision to the detriment of others. On the contrary, financial behavior must be approached from a holistic perspective because the three decisions are interdependent and are determined simultaneously (Kirch \& Terra, 2019). The traditional disconnect between these financial choices as supported by Modigliani and Miller (1958) is no longer defensible. To illustrate this point, it is asserted that investment decisions relate to the acquisition of assets, while financing decisions relate to how these assets can be financed. Dividends policy occurs when companies begin to generate profits and decides whether the firm should distribute some or all of the retained earnings to shareholders or reinvest them to seize investment opportunities.

\section{Method}

This section is dedicated to outlining methods and scientific tools applied in our study. To run a systematic review, a rigorous, and reproducible process has been carried out to collect, refine, and analyze the evolution of the literature on the financial behavior of family businesses. A systematic literature review is a synthesis of the scientific literature in response to a specific question. It uses explicit methods for searching, selecting, and analyzing data. A systematic review is, therefore, a scientific research method, and should not be confused with a "narrative" review in which the literature search is generally not exhaustive and is more representative of the opinion of authors.

Additionally, we conducted a bibliometric analysis since it is a statistical tool to assess the quantity and quality of publications, as well as the extent of success and achievements accomplished on our topic (Ellegaard \& Wallin, 2015). In this respect, we applied the methodology proposed by Tranfield, Denyer, and Smart (2003), which can be summarized in three main steps: planning the review, conducting the review, and then reporting results.

The focus of our bibliometric analysis lies at the intersection of the literature on family business and the literature on financial policy. While recognizing the complexity of the task, we conducted a preliminary literature review, known as a "scope" review (Tranfield et al., 2003), to delineate the area of investigation and determine some keywords. In a first step, we extracted some publications on financial decisions in family businesses. They are all written in English and reflect the three financial policies in the family business context. They helped to better explore the topic and identify keywords. Afterward, the search strings were performed using the Boolean operators OR and AND (Table $1)$.

Table 1. Core elements of bibliometric analysis

\begin{tabular}{|c|c|}
\hline Keywords & $\begin{array}{l}\text { " family business", " family enterprise", "family firm", "financial behavior", } \\
\text { "financial choice", "financial policy", "Investment", "risk-taking", "financing", } \\
\text { "funding", "debt", "capital structure", "financial structure", "dividend", "payout". }\end{array}$ \\
\hline Search strings & $\begin{array}{l}\text { ("family business*" OR "family enterprise*” OR "family firm*”) AND ("financ*” } \\
\text { OR "Invest*” OR "capital structure" OR "financial structure" OR "dividend" OR } \\
\text { "pay out") }\end{array}$ \\
\hline Scanned Items & Article title, Abstract, Keywords. \\
\hline \multirow[t]{3}{*}{ Sources/ Digital libraries } & Scopus \\
\hline & Web of Science \\
\hline & EBSCO host \\
\hline
\end{tabular}

Source: Authors' own

To ensure the richness of the data, we made sure that a wide range of databases was queried (Scopus, Web of Science, EBSCOhost). It is not a random selection, the three databases allow greater exhaustiveness and wide coverage of references from all corners of the world. Besides, these databases were used by many other published bibliometric studies (e.g. Coronado et al. (2011); Fetscherin and Heinrich (2015).

In a second step, initial search results revealed that many records are irrelevant to our topic of interest and had been included in our database. Thus, we decided on some eligibility criteria. The inclusion criteria concern: 1) documents from the following disciplines: Finance, Business, Management, or Accounting. 2) Documents that focus on corporate finance in family firms; 3) Documents written in English; 4) Peer-reviewed literature. Indeed, we have focused on the scientific literature published and evaluated by peers. To minimize the risk of bias, grey literature was 
rejected because it is not considered to be of scientific value.

Finally, the exclusion criteria concern 1) Documents that investigate financial policies within financial firms, public or nonprofit organizations; 2) Documents that use keywords in an economic context; 3) Case studies used in teaching.

These criteria were used to conduct a strict selection process (Figure 1) in order to purify and, above all, refine the search results. In addition, we did our best to validate the data by manual review and tried to give a close overall assessment by reading the full abstracts to understand the research purpose. This allowed us to confirm or deny the relevance of the retrieved documents. In order to have a comprehensive overview of our research topic, no period for analysis was predefined. This finally leads to a usable database reporting the metrics of 256 documents covering the period (1990- March 2020).
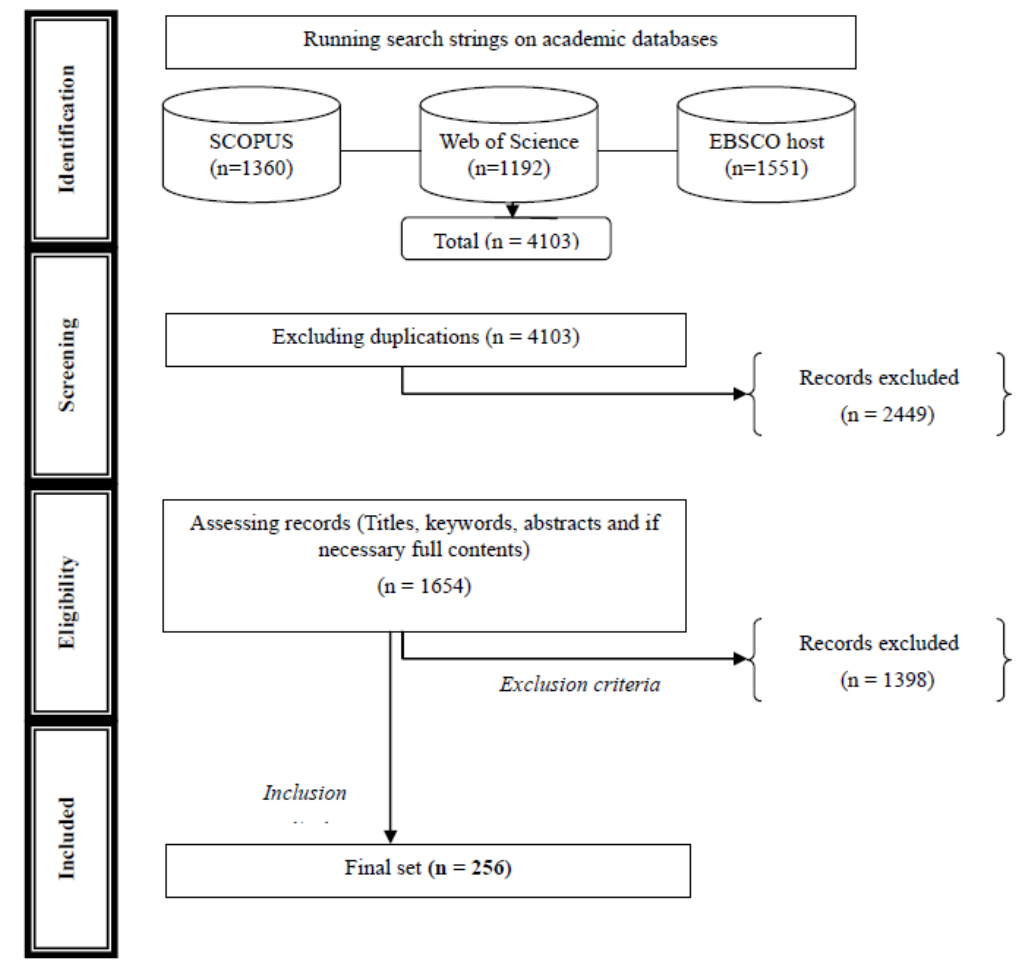

Figure 1. Flowchart of data selection

Afterward, we exported data into a Bibtex file. Some Excel processing was then performed. Finally, we used the Bibliometrix package which is the latest open-source software developed in the $\mathrm{R}$ environment to carry out systematic scientific-literature mapping (Aria \& Cuccurullo, 2017). The results of this analysis are reported in the following section.

\section{Results}

\subsection{Annual Scientific Production}

The evolution of the number of publications per year is an indicator of the interest that the scientific community attaches to a topic. According to the results presented in figure 2, there is a fluctuating but overall increasing trend since 1990. This shows that interest has increased over the years of studying the financial behavior of family businesses.

Moreover, it should be noted that $85 \%$ of the references were published over the last 10 years (2010 to 2020), 57\% were published in the last 5 years. The number of publications is growing at an annual rate of $7.25 \%$. 


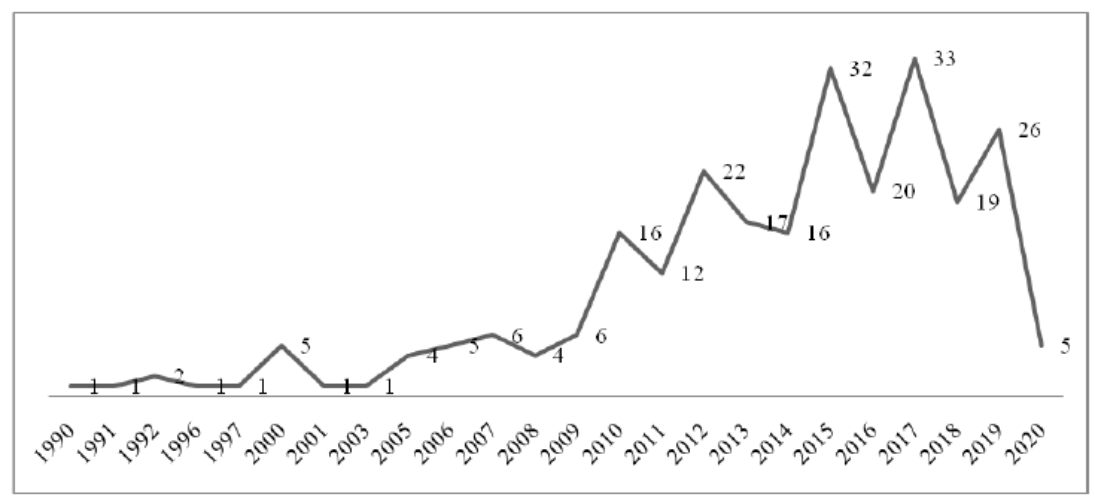

Figure 2. Annual scientific production

The 256 references take several forms: article, book chapter, proceeding, conference, review, eratum, note... However, the main mode of diffusion is the scientific article with 193 references, namely, $75 \%$ of total references.

\subsection{Sources}

The 256 references were retrieved from 151 sources (mainly journals and reviews). The top twenty sources bring together 101 references, i.e. $40 \%$ of the total scientific production. In addition, two journals that stand out by far as the most relevant which are "Family Business Review" with 22 articles (8\% of the references) and "the journal of Family Business Strategy" with 13 articles, i.e. 5\% of the references. These two journals alone account for $13 \%$ of all sources.

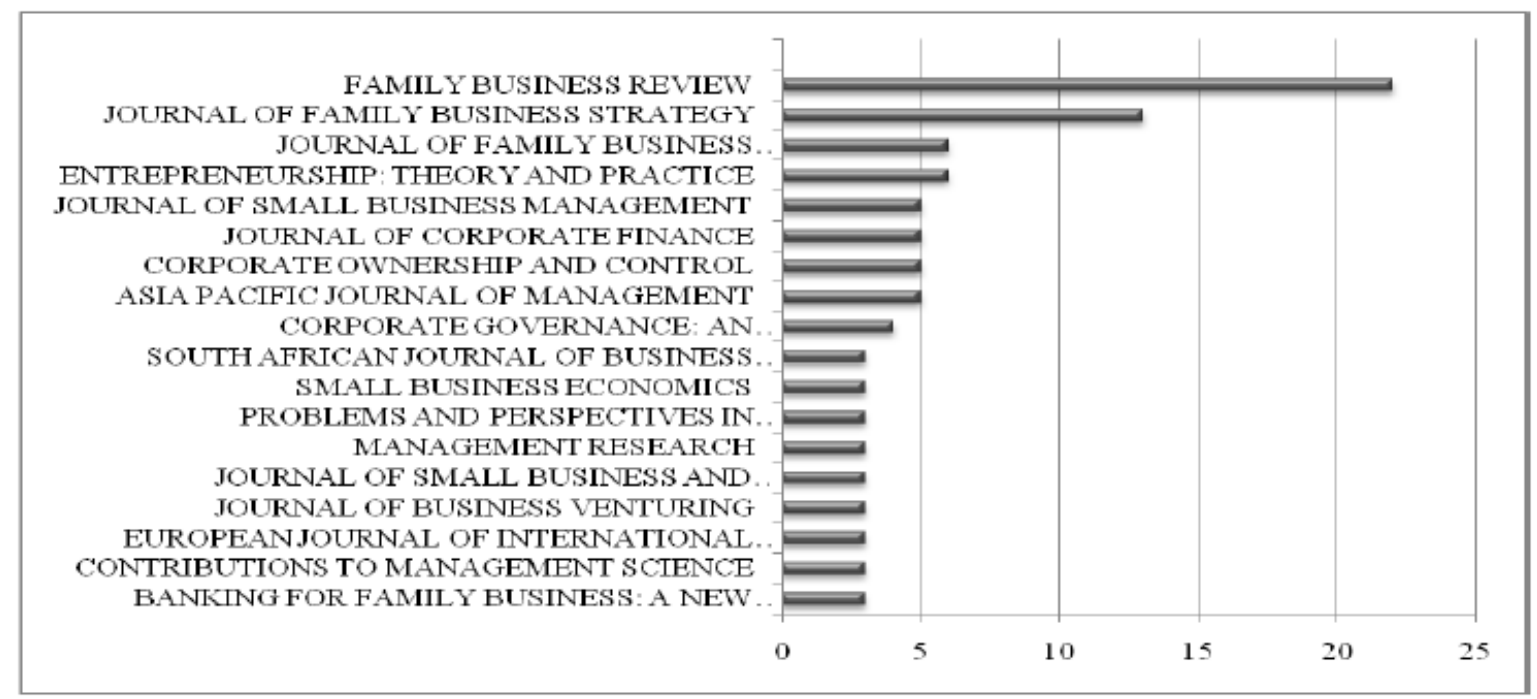

Figure 3. Most relevant sources

\subsection{Authors}

It is difficult to directly assess the quality of publications. However, the total number of citations received, the average number of citations per article, Hirsch-index (h-index), and the percentage of highly cited articles can be used as an indirect measure of publication impact or quality (Sweileh, \& al., 2016). As shown in Table 2, the 256 references were produced by 532 authors, some of whom appear several times, i.e. 2.08 authors per reference. The figure below shows the 20 most prolific authors. 
Table 2. Most relevant authors

\begin{tabular}{llll}
\hline Author & h_index & Total citations & Year_start \\
\hline GOTTARDO P & 3 & 35 & 2014 \\
\hline MOLLY V & 3 & 160 & 2008 \\
\hline DANES SM & 3 & 195 & 2000 \\
\hline GRICHNIK D & 3 & 97 & 2013 \\
\hline KELLERMANNS FW & 3 & 76 & 2014 \\
\hline KOROPP C & 3 & 97 & 2013 \\
\hline PATEL PC & 3 & 218 & 2014 \\
\hline PINDADO J & 3 & 84 & 2012 \\
\hline TAM OK & 3 & 24 & 2013 \\
\hline ACHLEITNER AK & 2 & 67 & 2012 \\
\hline DAWSON A & 2 & 68 & 2011 \\
\hline JORISSEN A & 2 & 46 & 2008 \\
\hline LAVEREN E & 2 & 150 & 2008 \\
\hline LUTZ E & 2 & 4 & 2012 \\
\hline MICHIELS A & 2 & 32 & 2015 \\
\hline MOISELLO AM & 2 & 13 & 2015 \\
\hline CASELLI S & 1 & 24 & 2005 \\
\hline CHEN J & 1 & 7 & 2010 \\
\hline DE QUEVEDO PUENTE E & 1 & 7 & 2009 \\
\hline TIAN Y & 1 & 3 & 2012 \\
\hline
\end{tabular}

Source: Authors' own

\subsection{Country Affiliation}

Scientific production on financial behavior in the family business context emerges from almost all the continents of the world, especially from 48 countries. The United States of America enjoy the greatest share of publications. Indeed, they account for $32 \%$ of the world's production with 82 references. However, we note that Africa and the Middle East are almost absent in the list, except for few countries that contribute, but slightly, to the clarification of this research topic, namely South Africa, Morocco, and Tunisia (figure 4).

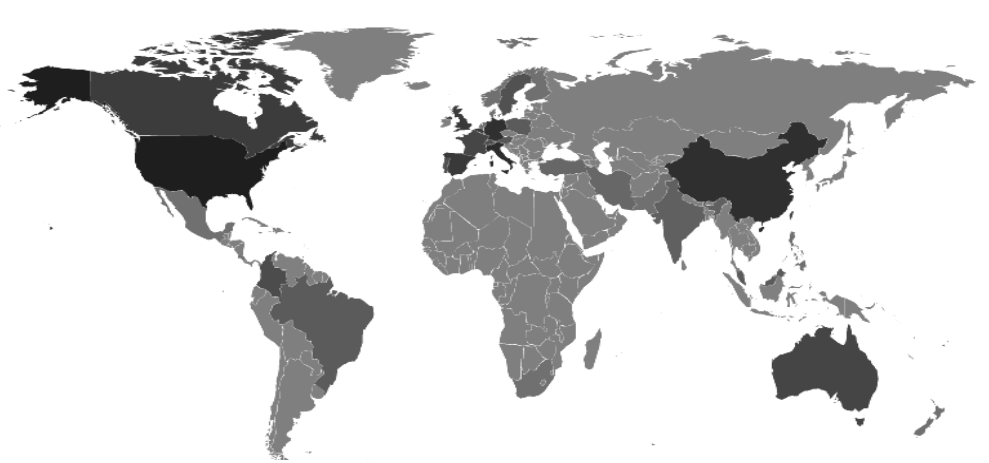

Figure 4. Dynamics of scientific production in the world

Note: Dark grey: high scientific production; light grey: low scientific production 
If we stratify countries by the number of citations per article, we assert that the USA and Australia ranked first with a total citation of 1410 with an average citation per article of 32.79 and 91.80 respectively (Table 3). The top 20 list includes 11 countries from northern and western Europe. Also, the Asian continent is present among the most prolific countries in terms of scientific production (mainly, China (162 citations), Malaysia (22), India (18), Hong Kong (16)).

Table 3. Citations per country

\begin{tabular}{lll}
\hline Country & Total Citations & Average Article Citations \\
\hline USA & 951 & 32.79 \\
\hline AUSTRALIA & 459 & 91.80 \\
\hline SPAIN & 344 & 31.27 \\
\hline ITALY & 257 & 13.53 \\
\hline BELGIUM & 194 & 19.40 \\
\hline CHINA & 162 & 5.59 \\
\hline SWEDEN & 142 & 47.33 \\
\hline GERMANY & 141 & 10.85 \\
\hline UNITED KINGDOM & 132 & 10.15 \\
\hline COLOMBIA & 91 & 18.20 \\
\hline DENMARK & 42 & 42.00 \\
\hline PORTUGAL & 39 & 9.75 \\
\hline NETHERLANDS & 33 & 33.00 \\
\hline AUSTRIA & 30 & 10.00 \\
\hline FRANCE & 27 & 3.86 \\
\hline MEXICO & 27 & 6.75 \\
\hline SWITZERLAND & 23 & 11.50 \\
\hline MALAYSIA & 22 & 3.67 \\
\hline INDIA & 18 & 9.00 \\
\hline HONG KONG & 16 & 8.00 \\
\hline
\end{tabular}

Source: Authors' own

In terms of collaboration, there are two indicators: single country publications (SCP) which report the number of articles published by authors belonging to the same country and multiple country publications (MCP) in which authors belong to different countries. Documents produced without international collaboration (SCP) are 82 articles, i.e 32\%. While international collaboration (MCP) represents 51\% with 131 articles. The remaining references had no country affiliation. Figure 5 show that China had the greatest extent of international collaboration. More than $61 \%$ of the references had co-authors from other countries. 


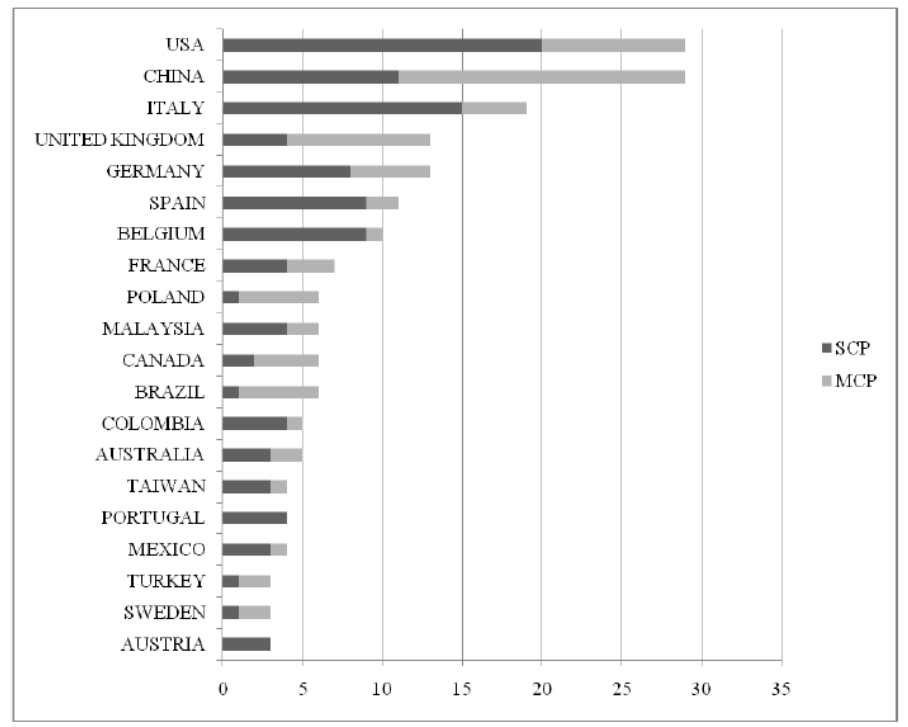

Figure 5. Inter and Intra- country collaboration

Note: Single country publications (SCP); multiple country publications (MCP)

\subsection{Top Cited Articles}

Top 20 cited articles on the financial behavior of family businesses are shown in Table 4. The article which obtained the highest number of citations is titled "Capital structure decision making: A model for family business" and published in 2001 by Romano, Tanewski \& Smyrnios in Journal of business venturing. It received 274 citations at the time of data analysis (March 24, 2020). In addition, seven articles from the top 20 cited articles were published in "Family Business Review".

Table 4. Top cited articles

\begin{tabular}{llll}
\hline Paper & Title & Total Citations & TC per Year \\
\hline ROMANO et al., 2001, & $\begin{array}{l}\text { Capital structure decision making: a model } \\
\text { for family business }\end{array}$ & 274 \\
\hline DANES et al., 2009, & $\begin{array}{l}\text { Family capital of family firms: bridging } \\
\text { human, social, and financial capital }\end{array}$ & 170 & 14.1667 \\
\hline PATEL \& CHRISMAN 2014, & $\begin{array}{l}\text { Risk abatement as a strategy for R\&D } \\
\text { investments in family firms }\end{array}$ & 150 & 21.4286 \\
\hline MASULIS et al., 2011, & $\begin{array}{l}\text { Family business groups around the world: } \\
\text { financing advantages, control motivations, } \\
\text { and organizational choices }\end{array}$ & \\
\hline GOMEZ-MEJIA et al., 2014, & $\begin{array}{l}\text { Socioemotional wealth as a mixed gamble: } \\
\text { revisiting family firm r\&d investments with } \\
\text { the behavioral agency model }\end{array}$ & \\
\hline CHIRICO et al., 2011, & $\begin{array}{l}\text { Resource orchestration in family firms: } \\
\text { investigating how entrepreneurial } \\
\text { orientation, generational involvement, and } \\
\text { participative strategy affect performance }\end{array}$ & \\
\hline GALLO \& VILASECA 1996, & Finance in family business & 13.7 \\
\hline MOLLY et al., 2010, & $\begin{array}{l}\text { Family business succession and its impact on } \\
\text { financial structure and performance }\end{array}$ & 112 \\
\hline DREUX, 1990, & Financing family business: alternatives to 109 & 3.5714 \\
\hline
\end{tabular}




\begin{tabular}{|c|c|c|c|}
\hline & selling out or going public & & \\
\hline MAZZI, 2011, & $\begin{array}{l}\text { Family business and financial performance: } \\
\text { current state of knowledge and future } \\
\text { research challenges }\end{array}$ & 106 & 10.6 \\
\hline $\begin{array}{l}\text { BLANCO-MAZAGATOS et } \\
\text { al., , 2007, }\end{array}$ & $\begin{array}{l}\text { The trade-off between financial resources } \\
\text { and agency costs in the family business: an } \\
\text { exploratory study }\end{array}$ & 96 & 6.8571 \\
\hline $\begin{array}{lcc}\text { LPEZ-GRACIA } & \& & S \\
\text { NCHEZ-ANDJAR, 2007, } & \end{array}$ & $\begin{array}{l}\text { Financial structure of the family business: } \\
\text { evidence from a group of small spanish firms }\end{array}$ & 76 & 5.4286 \\
\hline VAN AUKEN HE, 2006, & $\begin{array}{l}\text { An investigation of the determinants of } \\
\text { estate and retirement planning in } \\
\text { intergenerational family businesses }\end{array}$ & 70 & 4.6667 \\
\hline XU N et al., 2013, & $\begin{array}{l}\text { Political connections, financing friction, and } \\
\text { corporate investment: evidence from chinese } \\
\text { listed family firms }\end{array}$ & 70 & 8.75 \\
\hline DAWSON, 2011, & $\begin{array}{l}\text { Private equity investment decisions in family } \\
\text { firms: the role of human resources and } \\
\text { agency costs }\end{array}$ & 63 & 6.3 \\
\hline GOMEZ-MEJIA et al., 2018, & $\begin{array}{l}\text { In the horns of the dilemma: socio emotional } \\
\text { wealth, financial wealth, and acquisitions in } \\
\text { family firms }\end{array}$ & 62 & 20.6667 \\
\hline WAGNER et al.,, 2015, & $\begin{array}{l}\text { A meta-analysis of the financial performance } \\
\text { of family firms: another attempt }\end{array}$ & 61 & 10.1667 \\
\hline KOROPP et al., 2014, & $\begin{array}{l}\text { Financial decision making in family firms: } \\
\text { an adaptation of the theory of planned } \\
\text { behavior }\end{array}$ & 57 & 8.1429 \\
\hline ELLUL et al., 2010, & $\begin{array}{l}\text { Inheritance law and investment in family } \\
\text { firms }\end{array}$ & 57 & 5.1818 \\
\hline GONZLEZ et al., 2013, & $\begin{array}{l}\text { Family firms and debt: risk aversion versus } \\
\text { risk of losing control }\end{array}$ & 55 & 6.875 \\
\hline
\end{tabular}

Source: Authors' own

The retrieved articles discussed various issues related to financial policies within family businesses that cannot be reported here in detail. However, it is worth presenting some key points of 10 top-cited articles (Table 5).

Table 5. Main findings of 10 top cited articles

\begin{tabular}{|c|c|c|c|c|c|c|}
\hline Authors & Purpose and aims & Country & Methodology & Sample & Variables & Key finding \\
\hline $\begin{array}{l}\text { ROMANO et al. } \\
(2001)\end{array}$ & $\begin{array}{l}\text { To investigate the } \\
\text { capital structure of } \\
\text { SMEs and the factors } \\
\text { that influence SME } \\
\text { owner-managers' } \\
\text { financing decisions. }\end{array}$ & Australia & $\begin{array}{l}\text { Structural } \\
\text { equations }\end{array}$ & $\begin{array}{l}5000 \\
\text { business } \\
\text { owners }\end{array}$ & $\begin{array}{l}\text {-debt, } \\
\text {-family loans, } \\
\text {-capital and retained } \\
\quad \text { profits, } \\
\text {-equity } \\
\text {-Company size, } \\
\text {-firm age, } \\
\text {-industry, } \\
\text {-family control, } \\
\text {-age of CEO, } \\
\text {-business planning, }\end{array}$ & $\begin{array}{l}\text { - Dynamic interplay } \\
\text { between multiple } \\
\text { social, family, and } \\
\text { financial factors is } \\
\text { intricate; } \\
\text { - utilizing theories } \\
\text { enable researchers } \\
\text { to explain } \\
\text { behavioral factors } \\
\text { that influence } \\
\text { financial structure } \\
\text { decision-making } \\
\text { processes }\end{array}$ \\
\hline
\end{tabular}




\begin{tabular}{|c|c|c|c|c|c|c|}
\hline & & & & & -business objectives & \\
\hline $\begin{array}{l}\text { DANES et al. } \\
(2009)\end{array}$ & $\begin{array}{l}\text { to introduce a family } \\
\text { capital typology based } \\
\text { on Sustainable Family } \\
\text { Business Theory II and } \\
\text { to document its relative } \\
\text { effect to short-term firm } \\
\text { goals and long-term } \\
\text { sustainability }\end{array}$ & $\begin{array}{l}\text { United } \\
\text { States }\end{array}$ & $\begin{array}{l}\text { survey panel } \\
\text { data }\end{array}$ & $\begin{array}{l}311 \\
\text { family } \\
\text { firms }\end{array}$ & $\begin{array}{c}\text { Dependent variables: } \\
\text {-Gross business } \\
\text { revenue } \\
\text {-Perceived success } \\
\text { The independent variables } \\
\text {-Input controls } \\
\text {-Family structure } \\
\text {-Process controls } \\
\text {-Social capital } \\
\text {-Forms of family } \\
\text { capital } \\
\text {-Financial capital }\end{array}$ & $\begin{array}{lr}\text { family capital has } \\
\text { impacts } & \text { on } \\
\text { financial and } \\
\text { nonfinancial family } \\
\text { firm success }\end{array}$ \\
\hline $\begin{array}{l}\text { PATEL \& } \\
\text { CHRISMAN } \\
(2014)\end{array}$ & \begin{tabular}{lr}
\multicolumn{2}{c}{ To explain why and how } \\
family firms might \\
make different & R\&D \\
investments & than \\
nonfamily firms &
\end{tabular} & $\begin{array}{l}\text { United } \\
\text { States }\end{array}$ & $\begin{array}{l}\text { Generalized } \\
\text { least squares } \\
\text { fixed effects } \\
\text { regression }\end{array}$ & $\begin{array}{l}847 \\
\text { firms }\end{array}$ & $\begin{array}{l}\text { Dependent variable: sales } \\
\text { The independent variables } \\
\text { relate to inputs in: } \\
\text { - the production function } \\
\text { (yearly natural logs of R\&D } \\
\text { investments, capital } \\
\text { investments, advertising } \\
\text { investment, total number of } \\
\text { employees) } \\
\text { - risk abatement function } \\
\text { (family ownership, the } \\
\text { natural log of R\&D } \\
\text { investments, and the } \\
\text { interaction of the R\&D and } \\
\text { family ownership) }\end{array}$ & $\begin{array}{l}\text { When performance } \\
\text { is above (below) } \\
\text { aspiration levels, } \\
\text { the R\&D } \\
\text { investments of } \\
\text { family firms lead to } \\
\text { more (fewer) } \\
\text { exploitative patents } \\
\text { and fewer (more) } \\
\text { explorative patents } \\
\text { than in nonfamily } \\
\text { firm }\end{array}$ \\
\hline $\begin{array}{l}\text { MASULIS et al. } \\
(2011)\end{array}$ & $\begin{array}{ll}\text { To investigate } & \text { the } \\
\text { motivations } & \text { for } \\
\text { family-governed } & \\
\text { business groups. } & \end{array}$ & 45 countries & $\begin{array}{l}\text { Multivariate } \\
\text { regression }\end{array}$ & $\begin{array}{l}28 \quad 635 \\
\text { firms }\end{array}$ & $\begin{array}{l}\text {-Country-Level } \\
\quad \text { variables } \\
\text {-- Firm-level variables }\end{array}$ & $\begin{array}{l}\text { - particular group } \\
\text { structures emerge } \\
\text { not only to } \\
\text { perpetuate control } \\
\text { but also to alleviate } \\
\text { financing } \\
\text { constraints at the } \\
\text { country and } \\
\text { firm-level; } \\
\text { - investment } \\
\text { intensity is greater } \\
\text { for firms held in } \\
\text { pyramidal rather } \\
\text { than in horizontal } \\
\text { struct }\end{array}$ \\
\hline $\begin{array}{l}\text { GOMEZ-MEJIA } \\
\text { et al. (2014) }\end{array}$ & $\begin{array}{l}\text { To investigate the } \\
\text { socioemotional } \\
\text { trade-offs that R\&D } \\
\text { represents for the family } \\
\text { firm. }\end{array}$ & $\begin{array}{l}\text { United } \\
\text { States, } \\
\text { Canada }\end{array}$ & $\begin{array}{l}\text { Panel data } \\
\text { Tobit } \\
\text { Random- } \\
\text { Effect } \\
\text { Regression }\end{array}$ & $\begin{array}{l}2353 \\
\text { firms; } \\
142 \\
\text { family } \\
\text { firm, } \\
401 \\
\text { founder } \\
\text { firm and } \\
\text { nonfami }\end{array}$ & $\begin{array}{l}\text { Dependent Variable } \\
\text { R\&D Investments. } \\
\text { Independent and Moderator } \\
\text { Variables } \\
\text {-Family Firm } \\
\text {-Institutional } \\
\text { Ownership } \\
\text {-Related }\end{array}$ & $\begin{array}{l}\text { Family owners are } \\
\text { affected by the } \\
\text { potential for SEW } \\
\text { gains when making } \\
\text { R\&D investments. }\end{array}$ \\
\hline
\end{tabular}




\begin{tabular}{|c|c|c|c|c|c|c|}
\hline & & & & $\begin{array}{l}\text { ly-contr } \\
\text { olled } \\
\text { firms }\end{array}$ & $\begin{array}{c}\text { Diversification } \\
\text {-Performance Hazard. }\end{array}$ & \\
\hline $\begin{array}{l}\text { CHIRICO et al., } \\
(2011)\end{array}$ & $\begin{array}{l}\text { To investigate factors } \\
\text { that increase } \\
\text { performance through } \\
\text { entrepreneurship in } \\
\text { family firms. }\end{array}$ & Switzerland & $\begin{array}{l}\text { Regression } \\
\text { analysis }\end{array}$ & $\begin{array}{l}199 \\
\text { family } \\
\text { firms }\end{array}$ & $\begin{array}{l}\text { Dependent variable } \\
\text { Performance (net profit, } \\
\text { sales growth, cash flow, and } \\
\text { growth of net worth) } \\
\text { Independent variables } \\
\text { - Entrepreneurial orientation } \\
\text { (product innovation, } \\
\text { proactiveness, and risk } \\
\text { taking) } \\
\text { - generational involvement } \\
\text { - Participative strategy }\end{array}$ & $\begin{array}{l}\text { entrepreneurial } \\
\text { orientation, } \\
\text { generational } \\
\text { involvement, and } \\
\text { participative } \\
\text { strategy affect } \\
\text { entrepreneurship } \\
\text { perfomance in } \\
\text { family firms }\end{array}$ \\
\hline $\begin{array}{l}\text { GALLO \& } \\
\text { VILASECA } \\
(1996)\end{array}$ & $\begin{array}{l}\text { To examine the } \\
\text { characteristics of } \\
\text { financial issues faced by } \\
\text { family businesses and } \\
\text { their relationship with } \\
\text { performance. }\end{array}$ & Spain & $\begin{array}{l}\text { Linear } \\
\text { regression }\end{array}$ & $\begin{array}{l}104 \\
\text { family } \\
\text { business } \\
\text { es }\end{array}$ & $\begin{array}{l}\text {-Debt level } \\
\text {-Industry } \\
\text {-Market share } \\
\text {-Generation } \\
\text {-Company age } \\
\text {-Return on sales } \\
\text {-ROE } \\
\text {-Ln sales } \\
\text {-Ln assets } \\
\text {-Ln employees } \\
\text {-Number of financial } \\
\text { institutions the FB } \\
\text { is related to } \\
\text {-number of different } \\
\text { financial products } \\
\text { purchased by the } \\
\text { FB } \\
\text {-Dividends } \\
\text {-Asset turnover } \\
\text {-Sales/employees } \\
\text {-Investment risk }\end{array}$ & $\begin{array}{lr}\text { Family } & \text { firms have } \\
\text { low debt/equity } \\
\text { levels especially } \\
\text { those } \\
\text { important market } \\
\text { share positions in } \\
\text { their respective } \\
\text { industry. }\end{array}$ \\
\hline $\begin{array}{l}\text { MOLLY et al., } \\
(2010)\end{array}$ & $\begin{array}{l}\text { To study the effects of } \\
\text { family business } \\
\text { succession on debt and } \\
\text { growth rate. }\end{array}$ & Belgium & Panel data & $\begin{array}{l}152 \\
\text { firms }\end{array}$ & $\begin{array}{l}\text { Dependent variables: } \\
\text {-leverage } \\
\text {-performance } \\
\text {-profitability } \\
\text { Independent variables: } \\
\text {-Tangibility, } \\
\text {-age, } \\
\text {-size } \\
\text {-operating return on } \\
\text { assets } \\
\text {-gross return on assets } \\
\text {-Transfer } 1^{\text {st }} \text { to } 2^{\text {nd }} \\
\text { generation } \\
\text {-Transfer between later }\end{array}$ & $\begin{array}{l}\text { Succession from } \\
\text { the first to the } \\
\text { second generation } \\
\text { negatively affects } \\
\text { the debt rate of the } \\
\text { company and, the } \\
\text { effect is reversed in } \\
\text { the transfer } \\
\text { between later } \\
\text { generations. }\end{array}$ \\
\hline
\end{tabular}


generations

\begin{tabular}{|c|c|c|c|c|}
\hline DREUX (1990) & \multicolumn{4}{|c|}{$\begin{array}{l}\text { This paper is a general review that discusses the competing financial interests in family businesses and challenges they } \\
\text { present to intergenerational succession. It also focuses on the fact that alternatives to selling out or going public do exist. }\end{array}$} \\
\hline MAZZI (2011) & $\begin{array}{l}\text { To build a new } \\
\text { theoretical } \\
\text { framework } \\
\text { through literature } \\
\text { review about the } \\
\text { performance of } \\
\text { family businesses. }\end{array}$ & $\begin{array}{l}\text { Systematic } \\
\text { review }\end{array}$ & 23 articles & $\begin{array}{l}\text { Methodological approaches : } \\
\text { - Comparative (Family firms VS non family } \\
\text { firms) } \\
\text { - OLS multiple linear regression models } \\
\text { Performance variables } \\
\text { EBIT, EBITDA, ROA, ROE } \\
\text { Family firm performance is attached to: } \\
\text { - Family ownership/control } \\
\text { - Family management }\end{array}$ \\
\hline
\end{tabular}

Source: Authors' own

\subsection{Thematic Network}

With the purpose of drawing on conceptual analysis, it is usual, in a bibliometric review, to extract semantic links between author-defined keywords to represent the vital takeaway points of research in order to monitor progress of a particular research field (Mao \& Mooney, 2015). Bibliometrix tools were used to find out the most commonly encountered terms in keywords of retrieved documents. The figure visualizes thematic networks between keywords, leading to 5 clusters.

Many of the author- keywords are similar with slight variations, such as "agency theory", "agency costs", or "agency conflicts". Some keywords of interest to researchers can be related to governance such us (expropriation, minority shareholders, corporate control, succession). Dividends are also belonging to this cluster (red) which means that dividends as a sub-question are related to some governance concerns.

With regard to investment policy, it belongs to the blue cluster and it is attached to a range of keywords, mainly "financial constraints", "socioemotional wealth", "firm performance", "financial crisis" and "financial distress".

Interestingly, the capital structure decision is reflected in 4 clusters (orange, purple, blue, and green) with a high rate of occurrence of the word "debt". This result reveals the enigma of indebtedness as a source of financing and the complexity that it causes in terms of financial reporting quality, agency costs, and financial distress. Finally, the word "non-family firms" is also present in the network and refers to comparative empirical studies.

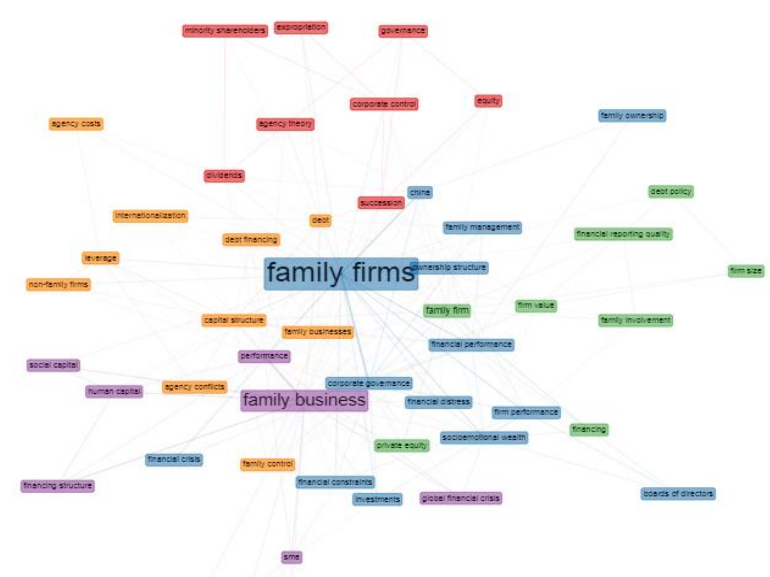

Figure 6. Thematic network

\subsection{Trend Topic Over Time}

By assessing the evolution of our topic over the last ten years, it can be noted that most of the keywords reflect the 
decision about the capital structure (debt, private equity, financing, leverage...). Interest in this financial policy lasted over the past decade. Regarding the investment decision, it has gained some attention in 2013 with the emergence of the keyword "financial constraints". In addition, we assert that the dividend policy has been significantly ignored and little explored by researchers.

Other keywords are involved in the topic such as performance and financial performance. Accordingly, some keywords enhance the behavioral dimension, such as "agency costs", "socioemotional wealth", "Ownership structure", "expropriation", "family management", "family control"... Consequently, the interest in these behavioral and social issues leads to an increased interest in corporate governance, which is the most frequent expression in our database (22 occurrences).

Recently, the focus has also been on internationalization strategy, due to market opening and globalization that have refurbished the global economy. In addition, "SME" is another frequent keyword on the list because some studies tried to categorize family businesses by firm size. This can be justified by the heterogeneity that characterized that type of business.

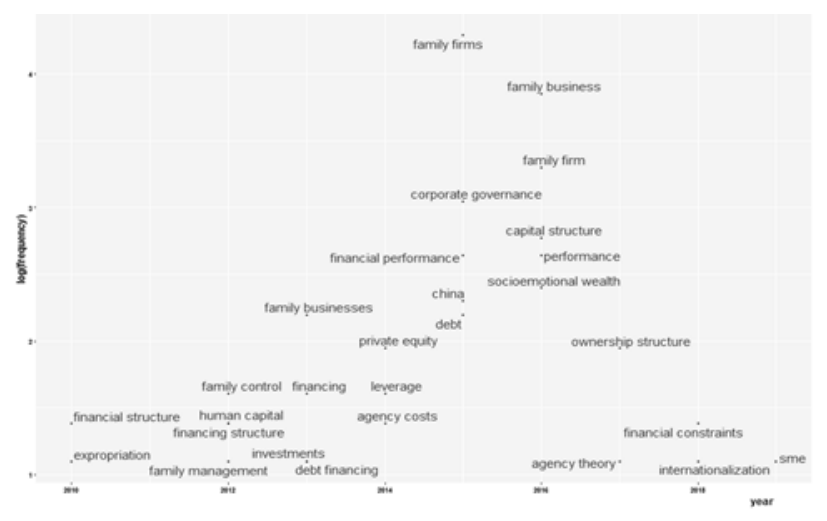

Figure 7. Topic evolution

\section{Discussion}

In this section, we intend to discuss and interpret the results of our review. Then, we will figure out some theoretical gaps leading to identify some future research avenues that may be of interest to scholars.

\subsection{General Trends}

Interestingly, research on family businesses has increased over years and this is supported by many previous works. Between 1977 and 1986, only 53 articles were devoted to the study of the family business (Allouche \& Amann, 2000), compared to 291 works between 2001 and 2007 (Debicki, Matherne III, Kellermanns \& Chrisman, 2009). In addition to that, bibliometric results have shown that financial decision making within family businesses is a growing field of research. That trend was reported by other works (Michiels, \& Molly, 2017; Lozano, 2015).

It can be argued, with discretion, that literature on the financial behavior of family businesses has been developed in the United States, Europe, Asia, and very modestly in Africa and the Middle East. As an emerging body of knowledge, the financial behavior of family businesses ranked in top productive and developed countries such as the United States of America and China. This is consistent with some works stating that researchers focus predominantly on family firms in developed economies (Bird, Welsch, Astrachan, \& Pistrui, 2002; Motylska-Kuzma, A. 2017). One explanation for this is that family businesses' preponderance in the economic system of these countries goes back decades or even centuries.

It is also worth noting that more than half of publications from all over the world came through international research collaboration. The latter becomes essential to broaden thinking in an era of globalization. Even more, this topic is of global concern, and research collaboration in this field is highly needed as stated by Bird et al. (2002).

\subsection{Theoretical Perspectives}

With regard to theories, the reviewed articles draw on a variety of approaches. This is consistent with the finding of 
other reviews on family businesses (Kubíček \& Machek, 2020). The dominant and common theoretical framework for the capital structure decision includes two traditional theories "the trade-off theory" and "the pecking order theory". This was also reported by Fama and French (2002) and Frank and Goyal (2003). As for investment and dividend policies, they involve theories from various disciplinary fields, such as "the behavioral agency model" by Patel and Chrisman (2014). In addition, the socioemotional wealth theory (Gomez-Mejia et al., 2007), resource-based view theory (Barney, 1991; Habbershon \& Williams, 1999), and the theory of planned behavior (Ajzen, 1991) have also been applied in studying the financial behavior of family businesses. These findings are supported by the works of Nordqvist, Melin, Waldkirch, and Kumeto (2015).

Empirical perspectives

The majority of reviewed articles conducted a quantitative approach. This trend was revealed by the works of Micelotta, Glaser, and Dorian (2020). In addition, capital structure is the policy that has gained a lot of empirical interest over years. This is consistent with the results of systematic reviews on financial decisions within family businesses, conducted by Motylska-Kuzma (2017) and Schickinger, Leitterstorf, and Kammerlander (2018). Research on financing and debt, in particular, has focused on empirical studies to identify the different factors guiding the capital structure choices within family businesses. To illustrate that, we cite the work of Romano et al (2001) that ranked first in reference to the number of citations. The authors highlight the significant impact of the factors attached to the specific nature of this category of firms. This is in line with the theory of planned behavior of Ajzen (1991) asserting that family firms are largely affected by family values, attitudes, perceived behavioral control, and behavioral intentions, which eventually influence decisions and choices (Koropp, Kellermanns, Grichnik \& Stanley 2014).

Focusing on the investment decision, the reviewed articles have focused mainly on R\&D investment (Patel \& Chrisman., 2014; Gomez-Mejia \& al., 2014) and on criteria that drive private equity (PE) investors in selecting family firms (Dawson, 2011). This policy was explored differently by Xu, N., Xu, X., and Yuan (2013) that examined the relationship between the political connectedness of family firms and underinvestment issues.

Regarding dividend policy, our results show that research has paid limited attention to dividend policy within family businesses over time. This was also stated by Björn and Eriksson Lantz (2016) that studied the ownership structure's effect on dividends. Consequently, the understanding of dividend payout antecedents in the context of family businesses is still ambiguous (Michiels et al., 2017).

Moving Forward: Future Research Agenda

Similar to other works that reviewed the financial behavior of family businesses (e.g., Motylska-Kuzma, 2017), our review draws up some promising directions for future research since the study of financial decisions in family businesses remains an interesting avenue to explore.

First, the analysis of the reviewed articles highlights the heterogeneity of family businesses and shows that researchers incorporate divergent criteria to define what a family business is. This question of heterogeneity has been confirmed by previous research (e.g. Missonier, \& Gundolf, 2017) and limits the accumulation of knowledge on family businesses (Schulze \& Gedajlovic, 2010). In this regard, the study of the financial behavior of family firms should begin by clearly defining the family firm. Following the recommendations of Arrègle and Mari (2010), the meaning of each definition criterion used should be precisely defined.

Second, we note that focus was given to the financial decisions, but separately. It may be interesting to expand the investigation and literature by combining the three financial policies at once since they are inseparable, simultaneous, and interactive. Building on these statements and integrating a cross-sectional structure (Smith \& Watts 1992) may help researchers to better understand how family businesses make their financial decisions.

Third, research on the financial behavior of family businesses should be holistic and oriented in a way to consider business characteristics, behavioral aspects of business, and financial factors. It should be considered as a co-alignment of multiple factors as stated by Chirico Sirmon, Sciascia, and Mazzola, (2011).

Fourth and methodologically speaking, researchers, through a series of quantitative studies, tried to identify some determinants of the three financial decisions. However, the impact or the explanatory power of these determinants remain attached to a very limited field of investigation and is not unanimously proved among authors. Thus far, this does not help to explore and to deeply understand the genesis of the financial policies within family businesses. In this respect, it will be crucial to shed light on qualitative approaches that offer flexibility and creativity and improve understanding of the complex processes within family businesses (Micelotta et al., 2020). 
Fifth, the notable absence or the knowledge gap on dividends policy in the literature represents strategic challenges and opportunities for future research as long as dividends have financial implications and contribute to value creation within the firm.

Sixth, in addition to comparisons between family businesses and non-family counterparts, it will be interesting to compare financial behavior across countries with different institutional settings and cultures. In line with the findings of Chrisman, Chua, and Steier (2002), the cultural context may shape business behavior and then affect financial decision-making.

\section{Conclusion}

The purpose of this paper was to supply a comprehensive overview of the financial behavior with special emphasis on family businesses. By reviewing the literature on the above matter, we conclude that great efforts have been made to explore family businesses and the peculiarities of their financial policies but, these efforts remain insufficient. The findings of this review highlighted that financial choices depend on several factors, both cognitive and emotional and that knowledge on capital structure decisions is still dispersed and inconclusive as reported by (Michiels \& Molly, 2017). Additionally, research on investment policy has been limited to the R\&D investment and private equity investors while research on dividends policy in family businesses was considerably underestimated.

As for the implications, this paper offers a valuable contribution to both family business and financial decisions research. It provides scholars with some insights and emerging gaps in financial policies within the specific case of family businesses and contributes to such a stream of literature by reporting patterns and trends using bibliometric analysis. Additionally, a systematic literature review enabled us to assess high-quality publications and to suggest some directions for future research useful to advance in this field. Our results have also several implications for family owners, managers, creditors, and all stakeholders as long as the success or failure of firms is often the result of financial decisions made by top management (Penney, Vardaman, Marler \& Antin-Yates, 2019). Consequently, all involved actors in family businesses must take an interest in the factors that drive and affect the financial decision-making process.

However, some limitations are noteworthy. First, an important limitation is related to the heterogeneity of the articles reviewed. Second, the keywords used in this review might not be too relevant or appropriate even if we had driven a scope literature review upstream. Third, limiting the selection process to publications written in English can also be a limitation. This methodological choice may have led to incomplete coverage of articles published on this topic.

For future developments, it would be of paramount interest to use more bibliometric tools (e.g., bibliographic coupling, co-citation analysis) in order to analyze in depth each relevant cluster or dimension identified in this review on the financial behavior in family businesses. Another area for further development is to perform the study over a long period using more keywords. All things considered, it is our hope that the insights highlighted in this paper will provide guidance to address gaps and to develop an accurate framework for the study of financial policies within the context of family businesses.

\section{Acknowledgment}

Authors would like to acknowledge the support of the CNRST (Centre National pour la Recherche Scientifique et Technique, Morocco).

\section{References}

Ajzen, I. (1991). The theory of planned behavior. Organizational Behavior and Human Decision Processes, 50(2), 179-211. https://doi.org/ 10.1016/0749-5978(91)90020-T

Allouche, J., \& Amann, B. (2000). L'entreprise familiale: un état de l'art. Finance Contrôle Stratégie, 3(1), 33-79.

Aria, M., \& Cuccurullo, C. (2017). Bibliometrix: An R-tool for comprehensive science mapping analysis. Journal of Informetrics, 11(4), 959-975. https://doi.org/ 10.1016/j.joi.2017.08.007

Arrègle, J. L., \& Mari, I. (2010). Avantages ou désavantages des entreprises familiales?. Revue Française de Gestion, (1), 87-109.

Arregle, J. L., Hitt, M. A., Sirmon, D. G., \& Very, P. (2007). The development of organizational social capital: Attributes of family firms. Journal of Management Studies, 44(1), 73-95. https://doi.org/10.1111/j.1467-6486.2007.00665.x

Auken, H. V. (2005). Differences in the usage of bootstrap financing among technology-based versus nontechnology-based firms. Journal of Small Business Management, 43(1), 93-103. 
https://doi.org/10.1111/j.1540-627X.2004.00127.x

Barney, J. (1991). Firm resources and sustained competitive advantage. Journal of Management, 17(1), 99-120. https://doi.org/10.1177/014920639101700108

Bird, B., Welsch, H., Astrachan, J. H., \& Pistrui, D. (2002). Family business research: The evolution of an academic field. Family Business Review, 15(4), 337-350.

Björn, L., \& Eriksson Lantz, C. (2016). Ownership structure's effect on dividend policy: Evidence from publicly listed Swedish firms.

Brenes, E. R., Madrigal, K., \& Requena, B. (2011). Corporate governance and family business performance. Journal of Business Research, 64(3), 280-285. https://doi.org/10.1016/j.jbusres.2009.11.013

Chaleeda, M., Islam, A., Ahmad, T. S. T., \& Ghazalat, A. N. M. (2019). The effects of corporate financing decisions on firm value in Bursa Malaysia. International Journal of Economics and Finance, 11(3), 127-135. https://doi.org/10.5539/ijef.v11n3p127

Chirico, F., Sirmon, D. G., Sciascia, S., \& Mazzola, P. (2011). Resource orchestration in family firms: Investigating how entrepreneurial orientation, generational involvement, and participative strategy affect performance. Strategic Entrepreneurship Journal, 5(4), 307-326. https://doi.org/10.1002/sej.121

Chrisman, J. J., Chua, J. H., \& Steier, L. P. (2002). The influence of national culture and family involvement on entrepreneurial perceptions and performance at the state level. Entrepreneurship Theory and Practice, 26(4), 113-130. https://doi.org/10.1177/104225870202600407

Chua, J. H., Chrisman, J. J., \& Sharma, P. (1999). Defining the family business by behavior. Entrepreneurship Theory and Practice, 23(4), 19-39. https://doi.org/10.1177/104225879902300402

Coronado, V. G., Xu, L., Basavaraju, S. V., McGuire, L. C., Wald, M. M., Faul, M., ... Hemphill, J. D. (2011). Surveillance for traumatic brain injury-related deaths; United States, 1997-2007.

Costa, D. F., Carvalho, F. D. M., \& Moreira, B. C. D. M. (2019). Behavioral economics and behavioral finance: A bibliometric analysis of the scientific fields. Journal of Economic Surveys, 33(1), 3-24. https://doi.org/10.1111/joes.12262

Dawson, A. (2011). Private equity investment decisions in family firms: The role of human resources and agency costs. Journal of Business Venturing, 26(2), 189-199. https://doi.org/10.1016/j.jbusvent.2009.05.004

Debicki, B. J., Matherne III, C. F., Kellermanns, F. W., \& Chrisman, J. J. (2009). Family business research in the new millennium: An overview of the who, the where, the what, and the why. Family Business Review, 22(2), 151-166. https://doi.org/10.1177/0894486509333598

El Azizi, T. B., \& Habba, B. (2018). Les effets des contraintes financières sur la dynamique des investissements des entreprises familiales de la région MENA. La Revue Gestion et Organisation, 10(1), 36-43.

Ellegaard, O., \& Wallin, J. A. (2015). The bibliometric analysis of scholarly production: How great is the impact?. Scientometrics, 105(3), 1809-1831. https://doi.org/10.1007/s11192-015-1645-z

Ernst \& Young. (2012). Built to last Family businesses lead the way to sustainable growth [Online]. Retrieved June 5, 2020, from http://www.ey.com/Publication/vwLUAssets/Built_to_Last/\$FILE/Built_to_Last.pdf

Fama, E. F., \& French, K. R. (2002). Testing trade-off and pecking order predictions about dividends and debt. The Review of Financial Studies, 15(1), 1-33. https://doi.org/10.1093/rfs/15.1.1

Fetscherin, M., \& Heinrich, D. (2015). Consumer brand relationships research: A bibliometric citation meta-analysis. Journal of Business Research, 68(2), 380-390. https://doi.org/10.1016/j.jbusres.2014.06.010

Frank, M. Z., \& Goyal, V. K. (2003). Testing the pecking order theory of capital structure. Journal of Financial Economics, 67(2), 217-248.

Gomez-Mejia, L. R., Campbell, J. T., Martin, G., Hoskisson, R. E., Makri, M., \& Sirmon, D. G. (2014). Socioemotional wealth as a mixed gamble: Revisiting family firm R\&D investments with the behavioral agency model. Entrepreneurship Theory and Practice, 38(6), 1351-1374. https://doi.org/10.1111/etap.12083

Gómez-Mejía, L. R., Haynes, K. T., Núñez-Nickel, M., Jacobson, K. J., \& Moyano-Fuentes, J. (2007). Socioemotional wealth and business risks in family-controlled firms: Evidence from Spanish olive oil mills. Administrative Science Quarterly, 52(1), 106-137. https://doi.org/10.2189/asqu.52.1.106 
Gottardo, P., \& Moisello, A. M. (2019). Family control and capital structure choices. In Capital structure, earnings management, and risk of financial distress (pp. 13-40). Springer, Cham.

Gyapong, E., Ahmed, A., Ntim, C. G., \& Nadeem, M. (2019). Board gender diversity and dividend policy in Australian listed firms: the effect of ownership concentration. Asia Pacific Journal of Management, 1-41. https://doi.org/10.1007/s10490-019-09672-2

Habbershon, T. G., \& Williams, M. L. (1999). A resource-based framework for assessing the strategic advantages of family firms. Family Business Review, 12(1), 1-25. https://doi.org/10.1111/j.1741-6248.1999.00001.x

Hultén, A. (2020). Family ownership and payout policy: A study of ownership and dividend policies in Swedish firms.

Kirch, G., \& Terra, P. R. (2019). Financial constraints and the interdependence of corporate financial decisions. RAUSP Management Journal. https://doi.org/10.1108/RAUSP-01-2019-0003

Koropp, C., Kellermanns, F. W., Grichnik, D., \& Stanley, L. (2014). Financial decision making in family firms: An adaptation of the theory of planned behavior. Family Business Review, 27(4), 307-327. https://doi.org/10.1177/0894486514522483

Kubíček, A., \& Machek, O. (2020). Intrafamily Conflicts in Family Businesses: A Systematic Review of the Literature and Agenda for Future Research. Family Business Review. https://doi.org/10.1177/0894486519899573

Lozano, M. B. (2015). Strategic decisions of family firms on cash accumulation. Revista de Administração de Empresas, 55(4), 461-466. https://doi.org/10.1590/S0034-759020150409

Mao, A. S., \& Mooney, D. J. (2015). Regenerative medicine: current therapies and future directions. Proceedings of the National Academy of Sciences, 112(47), 14452-14459. https://doi.org/10.1073/pnas.1508520112

Micelotta, E., Glaser, V. L., \& Dorian, G. (2020). Qualitative research in family business: methodological insights to leverage inspiration, avoid data asphyxiation and develop robust theory. In Handbook of Qualitative Research Methods for Family Business. Edward Elgar Publishing.

Michelli, D. (2014). Developing distinctive leaders: growing and sustaining family business.

Michiels, A., \& Molly, V. (2017). Financing decisions in family businesses: a review and suggestions for developing the field. Family Business Review, 30(4), 369-399. https://doi.org/10.1108/JSBED-01-2017-0023

Michiels, A., Uhlaner, L., \& Dekker, J. (2017). The effect of family business professionalization on dividend payout. Journal of Small Business and Enterprise Development.

Missonier, A., \& Gundolf, K. (2017). L'entreprise familiale: état et perspectives de la recherche francophone. Finance Contrôle Stratégie, (20-2). https://doi.org/10.4000/fcs.1933

Modigliani, F., \& Miller, M. H. (1958). The cost of capital, corporation finance and the theory of investment. The American, 1(3).

Motylska-Kuzma, A. (2017). The financial decisions of family businesses. Journal of Family Business Management. https://doi.org/10.1108/JFBM-07-2017-0019

Moussa, A. A., \& Elgiziry, K. (2019). The impact of family involvement in business on capital structure decisions: a literature review. Investment Management \& Financial Innovations, 16(1), 258. https://doi.org/10.21511/imfi.16(1).2019.20

Nordqvist, M., Melin, L., Waldkirch, M., \& Kumeto, G. (2015). Introducing theoretical perspectives on family business. In Theoretical perspectives on family businesses. Edward Elgar Publishing. https://doi.org/10.4337/9781783479665.00008

Nurlela, N., Sulastri, S., AJ, U. H., \& Hanafi, A. (2019). The influence of investment decisions and financing decisions on firm value with profitability as intervening variables (empirical study on companies listed in Indonesian Sharia Stock Index). International Journal of Multicultural and Multireligious Understanding, 6(2), 447-456. https://doi.org/10.18415/ijmmu.v6i2.758

Patel, P. C., \& Chrisman, J. J. (2014). Risk abatement as a strategy for R\&D investments in family firms. Strategic Management Journal, 35(4), 617-627. https://doi.org/10.1002/smj.2119

Penney, C., Vardaman, J., Marler, L., \& Antin-Yates, V. (2019). An image theory of strategic decision-making in 
family businesses. Journal of Family Business Management.

Poutziouris, P. Z. (2006). 30 The structure and performance of the UK family business PLC economy. Handbook of Research on Family Business, 552.

Romano, C. A., Tanewski, G. A., \& Smyrnios, K. X. (2001). Capital structure decision making: A model for family business. Journal of Business Venturing, 16(3), 285-310. https://doi.org/10.1016/S0883-9026(99)00053-1

Schickinger, A., Leitterstorf, M. P., \& Kammerlander, N. (2018). Private equity and family firms: A systematic review and categorization of the field. Journal of Family Business Strategy, 9(4), 268-292. https://doi.org/10.1016/j.jfbs.2018.09.002

Schulze, W. S., \& Gedajlovic, E. R. (2010). Whither family business?. Journal of Management Studies, 47(2), 191-204. https://doi.org/10.1111/j.1467-6486.2009.00887.x

Schulze, W. S., Lubatkin, M. H., Dino, R. N., \& Buchholtz, A. K. (2001). Agency relationships in family firms: Theory and evidence. Organization Science, 12(2), 99-116. https://doi.org/10.1287/orsc.12.2.99.10114

Seaman, C., Bent, R., \& Silva, M. (2019). Family values: Influencers in the development of financial and non-financial dynamics in family firms. In The Palgrave handbook of heterogeneity among family firms (pp. 507-530). Palgrave Macmillan, Cham. https://doi.org/10.1007/978-3-319-77676-7_19

Sharma, P., Chrisman, J. J., \& Gersick, K. E. (2012). 25 years of family business review: reflections on the past and perspectives for the future. https://doi.org/10.1177/0894486512437626

Shefrin, H. (2010). Behavioralizing finance. Foundations and Trends® in Finance, 4(1-2), 1-184. https://doi.org/10.1561/0500000030

Smith Jr, C. W., \& Watts, R. L. (1992). The investment opportunity set and corporate financing, dividend, and compensation policies. Journal of Financial Economics, 32(3), 263-292. https://doi.org/10.1016/0304-405X(92)90029-W

Sweileh, W. M., Al-Jabi, S. W., AbuTaha, A. S., Sa'ed, H. Z., Anayah, F. M., \& Sawalha, A. F. (2017). Bibliometric analysis of worldwide scientific literature in mobile-health: 2006-2016. BMC Medical Informatics and Decision Making, 17(1), 72. https://doi.org/10.1186/s12911-017-0476-7

Tranfield, D., Denyer, D., \& Smart, P. (2003). Towards a methodology for developing evidence-informed management knowledge by means of systematic review. British Journal of Management, 14(3), 207-222. https://doi.org/10.1111/1467-8551.00375

Vanauken, H. E., Ascigil, S., \& Carraher, S. (2017). Turkish SMEs' use of financial statements for decision making. The Journal of Entrepreneurial Finance (JEF), 19(1). Retrieved from https://digitalcommons.pepperdine.edu/jef/vol19/iss1/6

Xu, N., Xu, X., \& Yuan, Q. (2013). Political connections, financing friction, and corporate investment: Evidence from Chinese listed family firms. European Financial Management, 19(4), 675-702. https://doi.org/10.1111/j.1468-036X.2011.00591.x

\section{Copyrights}

Copyright for this article is retained by the author(s), with first publication rights granted to the journal.

This is an open-access article distributed under the terms and conditions of the Creative Commons Attribution license (http://creativecommons.org/licenses/by/4.0/). 